JURNAL ILMIAH ELEKTRONIKA DAN KOMPUTER, Vol.14, No.1, July 2021, pp. 130 - 140

p-ISSN : $1907-0012$ (print)

e-ISSN : 2714-5417 (online)

http://journal.stekom.ac.id/index.php/elkom

- page 130

\title{
Penerapan Konsep Finite State Automata Pada Aplikasi Simulasi Vending Machine Beras
}

\author{
Anggun Yuli Asih', Rini Novi Ambarwati ${ }^{2}$, Eni Heni Hermaliani ${ }^{3}$, Tuti Haryanti ${ }^{4}$ Windu Gata $^{5}$ \\ 1,2,3,4,5 Jurusan Ilmu Komputer, Universitas Nusa Mandiri \\ Jl. Kramat Raya No.98, RT.2/RW.9, Kwitang, Kec. Senen, Kota Jakarta Pusat, Daerah Khusus Ibukota \\ Jakarta 10450, (021) 21231170 \\ e-mail: 14207070@nusamandiri.ac.id¹,14207079@nusamandiri.ac.id²,enie_h@nusamandiri.ac.id ${ }^{3}$, \\ tuti@nusamandiri.ac.id ${ }^{4}$, windu@nusamandiri.ac.id ${ }^{5}$
}

\begin{tabular}{|c|c|}
\hline ARTICLE INFO & ABSTRACT \\
\hline $\begin{array}{l}\text { Article history: } \\
\text { Received } 30 \text { Mei } 2021 \\
\text { Received in revised form } 2 \text { juni } 2021 \\
\text { Accepted } 10 \text { juni } 2021 \\
\text { Available online july } 2021\end{array}$ & $\begin{array}{l}\text { Indonesia is known as an agrarian country } \\
\text { because it has abundant natural resources that } \\
\text { are supported by fertile soil so that the majority } \\
\text { of the people make a living as farmers. One of } \\
\text { the agricultural products that contribute to } \\
\text { poverty in Indonesia is rice. Rice can easily be } \\
\text { found in markets, both traditional markets and } \\
\text { modern markets, but in the midst of the current } \\
\text { coronavirus (COVID-19) pandemic, people are } \\
\text { afraid to go to the market because the market is } \\
\text { one of the largest clusters of Covid-19 } \\
\text { transmission. One of the technological } \\
\text { innovations that has been widely used in the } \\
\text { world of commerce is vending machine (VM). } \\
\text { VM is an automatic sales machine that is } \\
\text { usually found in crowded and strategic places. } \\
\text { This is the basis for making a rice VM } \\
\text { simulation and is expected to be one of the } \\
\text { solutions to stop the spread and transmission of } \\
\text { COVID-19. This rice VM simulation can auto- } \\
\text { sell rice by entering in the form of paper money } \\
\text { or with e-money and the output in the form of a } \\
\text { rice purchase receipt and } 5 \text { types of rice. The } \\
\text { method used is Finite State Automata (FSA) } \\
\text { type Non-deterministic Finite State Automata } \\
\text { (NFA) which is defined by five tuples, with the } \\
\text { formula: M = (Q, } \Sigma \text {, } \delta \text {, S, F). NFA was chosen } \\
\text { because it can explain the working concept in } \\
\text { detail so that it is easy to understand and the } \\
\text { results of the FSA can be made into simple } \\
\text { logical concepts for implementation. }\end{array}$ \\
\hline
\end{tabular}

Keywords: Finite State Automata, Vending Machine, Rice

\section{ABSTRAK}


Indonesia terkenal sebagai negara agraris karena memiliki sumber daya alam melimpah yang didukung dengan tanah subur sehingga masyarakatnya mayoritas bermatapencaharian sebagai petani. Salah satu hasil pertanian yang berkontribusi terhadap kemiskinan di Indonesia yaitu beras. Beras dengan mudah dapat ditemukan di pasar baik pasar tradisional maupun pasar modern, namun ditengah pandemi virus corona (COVID-19) sekarang ini membuat orang merasa takut untuk pergi ke pasar karena pasar merupakan salah satu klaster terbesar penularan covid-19. Salah satu inovasi teknologi yang telah banyak digunakan dalam dunia perniagaan yaitu vending machine (VM). VM merupakan sebuah mesin penjualan otomatis yang biasanya terdapat di tempat ramai dan strategis. Hal ini yang mendasari untuk pembuatan simulasi VM beras dan diharapkan dapat menjadi salah satu solusi pemutus penyebaran dan penularan covid-19. Simulasi VM beras ini dapat melakukan penjualan otomatis beras dengan masukkan berupa uang kertas atau dengan e-money dan keluarannya berupa struk bukti pembelian beras dan 5 jenis beras. Metode yang digunakan yaitu Finite State Automata (FSA) jenis Non-deterministic Finite State Automata (NFA) yang didefinisikan lima tupel, dengan rumus: $\mathrm{M}=(\mathrm{Q}, \Sigma, \delta, \mathrm{S}, \mathrm{F})$. NFA dipilih karena dapat menjelaskan konsep kerja secara rinci sehingga mudah dipahami dan hasil dari FSA dapat dibuat konsep logika sederhana untuk implementasi.

Kata Kunci: Finite State Automata, Vending Machine, Beras

\section{PENDAHULUAN}

Indonesia terkenal dengan sumber daya alamnya yang melimpah terutama dibidang pertanian. Masyarakat Indonesia sebagian besar bermata pencaharian sebagai petani karena Indonesia mempunyai struktur tanah yang baik untuk bercocok tanam dan juga beriklim tropis. Salah satu hasil pertanian yang juga merupakan makanan pokok masyarakat Indonesia adalah Beras [1].

Coronavirus (virus corona) atau biasa juga disebut COVID-19 merupakan sekumpulan virus dari subfamili Orthocronavirinae dalam keluarga Coronaviridae dan ordo Nidovirales. Kelompok virus ini dapat menyerang pada burung dan mamalia, termasuk manusia yang dapat mengakibatkan kematian. Virus ini sangat berbahaya jika terkena pada manusia. Gejala yang dialami pada manusia berupa gangguan saluran pernapasan seperti pilek, hal ini akan membuat orang awam menghiraukan virus ini karena gejalanya yang terlihat seperti influenza biasa tetapi bagi analisis kedokteran virus ini dianggap berbahaya dan mematikan [2].

Perkembangan penularan virus corona ini sangatlah cepat hingga sekarang di tahun 2011 pun selalu meningkat kasus penularannya di Indonesia maupun di dunia. Menurut [3] dalam Kompas.com berdasarkan data Satuan Tugas (Satgas) Penanganan Covid-19, dalam waktu 24 jam kasus pasien positif bertambah hingga 5.862 orang, terhitung pada kamis 27 Mei 2021 hingga jumat 28 Mei 2021 di Indonesia. Pemerintah telah melakukan berbagai upaya untuk mengurangi penyebaran virus corona di seluruh daerah Indonesia dengan membatasi aktifitas diluar rumah mulai dari kegiatan sekolah yang dilakukan di rumah secara daring, bekerja dari rumah (work from home) dan kegiatan ibadah juga harus dilakukan dirumah [2].

Pemerintah juga menetapkan protokol kesehatan yang wajib dipatuhi oleh semua masyarakat Indonesia dengan aturan 5M (Memakai masker, Menjaga jarak, Mencuci tangan, Menjauhi kerumunan, dan Mengurangi mobilitas). Ditengah pandemi virus corona yang semakin menyebar luas terutama di Indonesia, membuat kita harus selalu waspada dan menjaga diri dengan mematuhi aturan protokol kesehatan. Penerapan protokol kesehatan menjadi kunci penting pencegahan penyebaran covid-19. Hal ini bisa dilakukan dengan penerapan kedisiplinan didalam rumah dan mengurangi aktivitas diluar rumah, namun kegiatan diluar rumah tidak bisa dihindari terus menerus, adakalanya kegitan juga harus dilakukan diluar rumah seperti olahraga, atau bahkan berbelanja kebutuhan pokok di pasar. Pasar merupakan tempat bertemunya penjual

Penerapan Konsep Finite State Automata Pada Aplikasi Simulasi Vending Machine Beras

(Anggun Yuli Asih) 
dan pembeli sampai terjadinya suatu transaksi. Perkembangan pasar saat ini bukan hanya pasar tradisional saja [4]. Pasar dibedakan menjadi pasar tradisional dan pasar modern. Menurut Suprapto, Pasar tradisional adalah tempat pembeli dan penjual saling bertemu dan melakukan kegiatan transaksi kebutuhana sehari-hari yang mempunyai unsur-unsur sosial, ekonomis, kebudayaan, politis dan lain-lain serta telah resmi diakui pemerintah [5]. Baik di pasar tradisional maupun modern sekarang banyak menjual bahan pokok seperti minyak, gula, sayur, buah, daging, susu dan lain sebagainya terutama beras yang menjadi makanan pokok masyarakat Indonesia dan salah satu klaster penyebaran virus corona ada di pasar, oleh karena itu perlu adanya tindakan agar masyarakat tidak berkerumun dan terhindar dari penularan virus corona.

Perkembangan teknologi informasi yang semakin canggih dan berkembang merubah sebagian besar gaya hidup masyarakat terutama di Indonesia yang awalnya tradisional menjadi modern dan mendorong munculnya ide-ide baru maupun inovasi-inovasi pengembangan berbagai macam produk. Salah satu teknologi yang telah dikembangkan dalam kehidupan masyarakat secara luas adalah vending machine (VM) [6]. Hal ini juga yang mendasari untuk pembuatan simulasi VM beras. Metode yang diterapkan dalam penelitian ini menggunakan Finite State Automata (FSA). Aplikasi simulasi VM ini menghasilkan keluaran beras dan struk bukti pembelian beras dengan masukannya berupa uang kertas atau bisa juga dengan tapping kartu $e$ money. Dengan adanya penelitian ini diharapkan dapat lebih berguna bagi masyarakat dalam efisiensi waktu berbelanja kebutuhan pokok terutama beras dan diharapkan dapat menjadi salah satu solusi pemutus penyebaran dan penularan virus corona di masa pandemi seperti ini.

\section{LANDASAN TEORI}

Menurut Abidin, Beras merupakan makanan pokok masyarakat Indonesia yang paling banyak dikonsumsi dan merupakan barang niaga yang memberikan sumbangan terbesar pada garis kemiskinan baik di perkotaan ataupun di perdesaan [7]. Beras merupakan bahan pangan pokok masyarakat Indonesia yang berasal dari padi yang ditanam di sawah. Cara memperoleh beras yaitu dari padi yang telah dipanen kemudian gabah dipisahkan dari merang. Gabah yang sudah terpisah dari merang selanjutnya dijemur sampai kering kemudian gabah digiling untuk memisahkan kulit gabah dari beras, dan beras siap untuk dipasarkan maupun diolah menjadi nasi atau makanan lain [8].

Finite State Automata (FSA) merupakan pemodelan matematika dengan masukan berupa sejumlah himpunan terbatas. FSA juga memiliki sekumpulan state yang berhingga, sebuah state awal, dan fungsi transisi untuk berpindah state, serta himpunan bagian dari state untuk menerima hasil menjadi keluaran [9]. Menurut Adenis dan Ray, Teori bahasa dan automata merupakan bagian yang sangat berguna untuk pengembangan ilmu komputer lebih lanjut baik dalam hardware (perangkat keras) dan software (perangkat lunak). Teori bahasa bertindak sebagai sarana komunikasi baik sesama manusia ataupun antara manusia dan mesin, sedangkan teori automata adalah teori mengenai mesin-mesin abstrak, dan berkaitan erat dengan teori bahasa formal. Automata dapat diterapkan pada aplikasi simulasi VM [10].

Vending Machine (VM) pertama kali menggunakan kayu sebagai bahan dasar dan hadir di Jepang pada tahun 1930. VM banyak dimanfaatkan negara-negara berkembang untuk memudahkan transaksi jual beli barang. Menurut Atina et al, VM merupakan toko elektronik berbentuk kotak dari besi dan bagian depan dilapisi dengan kaca yang menjual berbagai macam kebutuhan manusia seperti makanan, minuman, tiket dan lain sebagainya [11].

Penelitian sebelumnya VM yang menggunakan FSA juga digunakan dalam Aplikasi Simulasi Penjualan Susu Kambing Etawa, dengan rancangan FSA menggunakan dua sistem pembayaran yaitu tunai dan e-money menggunakan kartu [12], Aplikasi simulasi penjualan jamu tradisional [13], Desain VM pada simulasi penjualan rujak buah [14], Desain VM Rokok terintegrasi KTP untuk mengurangi perokok aktif yang berusia dibawah umur [15], dan pada Simulasi VM Dengan Mengimplementasikan FSA, yaitu menggunakan simulasi VM minuman sederhana dengan masukan uang pecahan logam 500 dan 1000. Output minuman yang

JURNAL ILMIAH ELEKTRONIKA DAN KOMPUTER Vol. 14, No. 1, Desember 2021 : 130 -140 
dikeluarkan yaitu Buavita, Nescafe, Ultra Milk, Hilo dan dalam VM ini juga dapat memberikan kembalian jika uang yang dimasukkan lebih besar dari harga minuman yang dibeli. Kesimpulan dalam penelitian simulasi VM minuman sederhana ini yaitu bahwa penggunaan FSA pada VM sesuai didalam cara kerjanya, dan finite state sebagai dasar dari pengoperasian simulasi tersebut menjelaskan alur secara rinci sehingga prosesnya mudah dipahami [16].

Penelitian ini dibuatkan sebuah aplikasi simulasi VM yang dapat melakukan proses transaksi penjualan otomatis beras. Input berupa uang kertas sebesar Rp 1.000, Rp 2.000, Rp 5.000, Rp 10.000, Rp 20.000, Rp 50.000, Rp 75.000 dan Rp 100.000 atau bisa juga menggunakan e-money. VM ini juga menyediakan kembalian uang. Output VM ini berupa 5 jenis beras yaitu Beras Pandan Wangi, Beras Rojolele, Beras Setra Ramos, Beras IR42, dan Beras Solok serta bukti struk yang akan dikeluarkan dari VM bersamaan dengan keluarnya beras. Beras yang dikeluarkan dari VM ini sudah dalam kemasan plastik per $1 \mathrm{~kg}$, per $5 \mathrm{~kg}$, dan per $10 \mathrm{~kg}$. Penelitian ini menggunakan FSA karena hasil FSA sebagai dasar pengoperasian VM sangat sederhana dan menjelaskan konsep kerja secara rinci sehingga mudah dipahami. Hasil dari diagram FSA dapat dibuat konsep logika sederhana untuk implementasi VM [17].

\section{METODE PENELITIAN}

Tahapan-tahapan metode yang dilakukan dalam penelitian ini yaitu dengan menggunakan FSA VM Beras, Perancangan Sistem VM Beras, dan Desain VM Beras. Tahapan pertama menggambarkan rancangan diagram FSA menggunakan Non-Deterministik Finite Automata (NFA), dimana masukan (input) memiliki lebih dari 1 keluaran atau bahkan tidak memiliki keluaran. Tahapan kedua menjelaskan rancangan sistem VM Beras dengan menggunakan Unified Modelling Language (UML) yang terdiri dari Usecase Diagram dan Activity Diagram. Tahap terakhir yaitu mendesain tampilan antarmuka VM Beras ketika diimplementasikan.

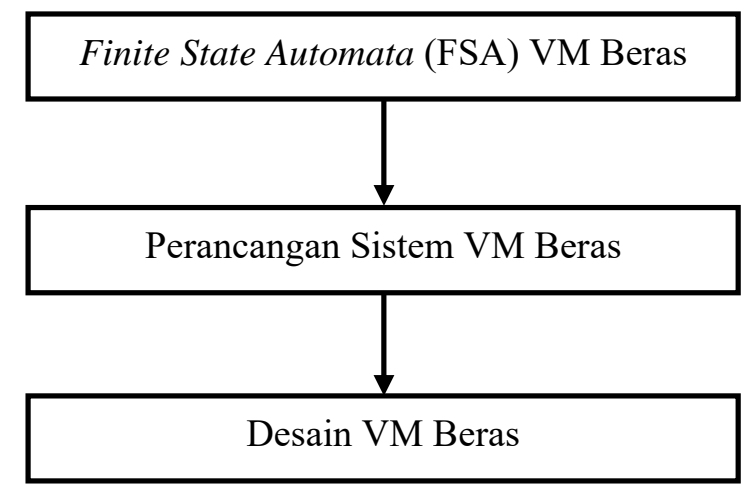

Gambar 1. Metode Penelitian

\section{HASIL DAN PEMBAHASAN}

\subsection{Finite State Automata (FSA)}

State diagram yang digunakan yaitu dengan FSA dengan konsep Non-Deterministic Finite Automata (NFA) karena dapat menuju ke beberapa state jika suatu state diberi input. NFA didefinisikan dengan lima tupel, dengan rumus: $\mathrm{M}=(\mathrm{Q}, \Sigma, \delta, \mathrm{S}, \mathrm{F})$, sehingga dapat didefinisikan sebagai berikut:

$$
\begin{aligned}
& \mathrm{Q}=\left\{\mathrm{Q}_{0}, \mathrm{Q}_{1}, \mathrm{Q}_{3}, \mathrm{Q}_{4}, \mathrm{Q}_{5}, \mathrm{Q}_{6}, \mathrm{Q}_{7}, \mathrm{Q}_{8}, \mathrm{Q}_{9}, \mathrm{Q}_{10}, \mathrm{Q}_{11}\right\} \\
& \Sigma=\{\mathrm{a}, \mathrm{b}, \mathrm{c}, \mathrm{d}, \mathrm{e}, \mathrm{f}, \mathrm{g}, \mathrm{h}, \mathrm{i}, \mathrm{j}\} \\
& \mathrm{S}=\left\{\mathrm{Q}_{0}\right\} \\
& \mathrm{F}=\left\{\mathrm{Q}_{11}\right\}
\end{aligned}
$$




\section{Keterangan:}

$0=$ Tidak ada

$1=$ Mengeluarkan Beras

$\mathrm{Q}_{0}=$ State awal

$\mathrm{Q}_{1}=$ Beras Pandan Wangi

$\mathrm{Q}_{2}=$ Beras Rojolele

$\mathrm{Q}_{3}=$ Beras Setra Ramos

$\mathrm{Q}_{4}=$ Beras IR42

$\mathrm{Q}_{5}=$ Beras Solok

$\mathrm{Q}_{6}=$ Isi $1 \mathrm{Kg}$

$\mathrm{Q}_{7}=$ Isi $5 \mathrm{Kg}$

$\mathrm{Q}_{8}=$ isi $10 \mathrm{Kg}$

$\mathrm{Q}_{9}=$ Tipe Pembayaran Tunai

$\mathrm{Q}_{10}=$ Tipe Pembayaran E-money

$\mathrm{Q}_{11}=$ Struk keluar (state akhir)

$\mathrm{a}=$ Masukkan Beras Pandan Wangi

$\mathrm{b}=$ Masukkan Beras Rojolele

$\mathrm{c}=$ Masukkan Beras Setra Ramos

$\mathrm{d}=$ Masukkan Beras IR42

$\mathrm{e}=$ Masukkan Beras Solok

$\mathrm{f}=$ Masukkan Isi $1 \mathrm{Kg}$

$\mathrm{g}=$ Masukkan isi $5 \mathrm{Kg}$

$\mathrm{h}=$ Masukkan Isi $10 \mathrm{Kg}$

$\mathrm{i}=$ Masukkan Pembayaran Tunai

$\mathrm{j}=$ Masukkan Pembayaran E-money

$\mathrm{k}=$ konfirmasi selesai 


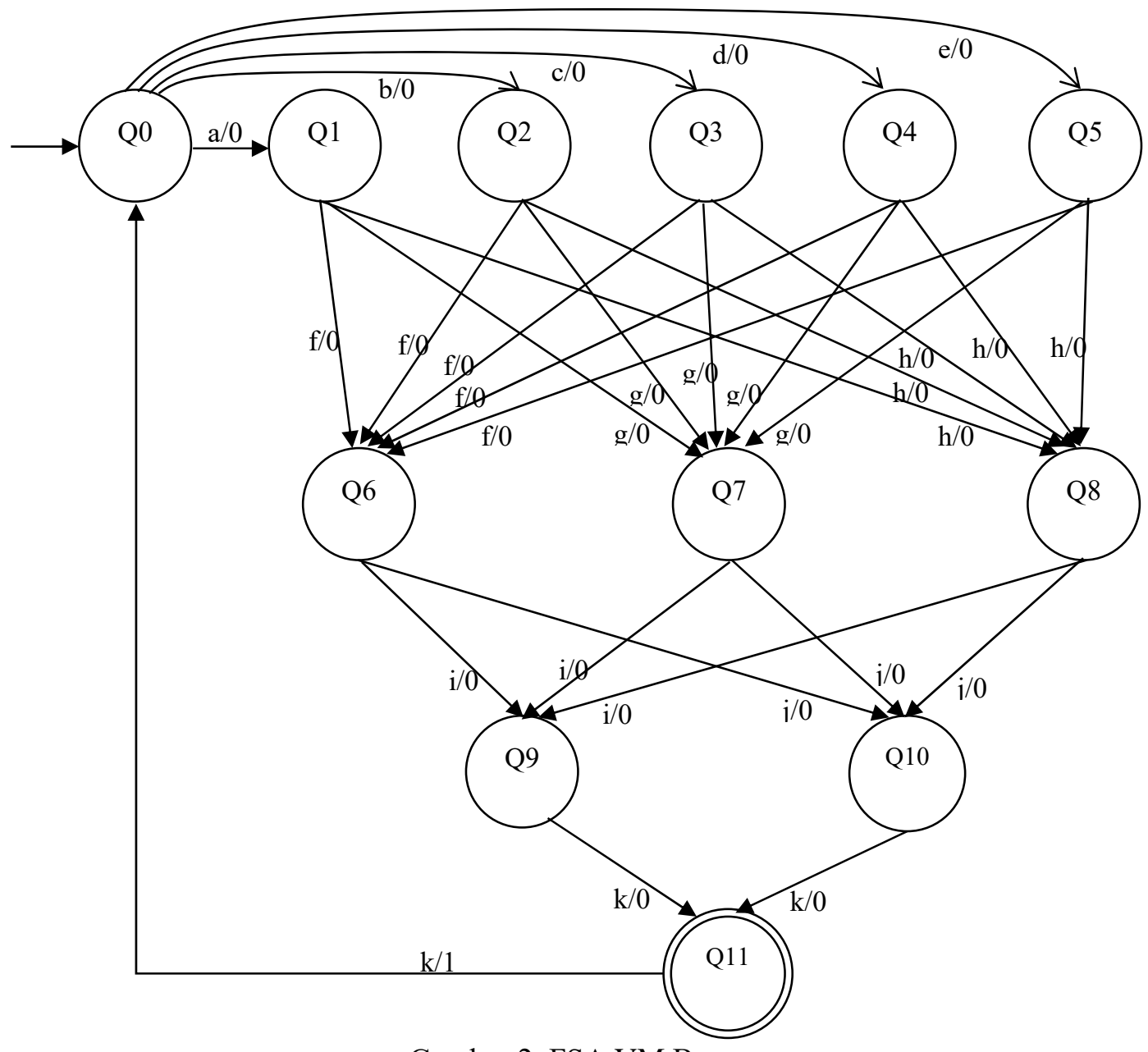

Gambar 2. FSA VM Beras

Diagram state tersebut menerima masukan berupa state yang akan dituju serta nol dan satu. Nol berarti diagram state tersebut berlanjut ke state berikutnya, sedangkan menerima masukan satu berarti mesin telah menyelesaikan tugasnya (sudah mengeluarkan struk dan beras keluar) dan akan kembali ke state awal. Diagram state tersebut juga memiliki beberapa masukan spesial untuk pembayaran tunai dan non-tunai, sedangkan, untuk state yang dituju, disimbolkan masukannya dengan huruf kecil dari state yang akan dituju. Mesin tersebut akan berjalan apabila masukan yang dituju sesuai dengan state yang akan dituju.

Pada state awal, pengguna akan diminta untuk memilih jenis beras apa yang diinginkan, misalnya pengguna memilih beras pandan wangi, maka state awal Q0 akan menuju ke state Q1. Setelah beras dipilih maka akan muncul pilihan isi beras $1 \mathrm{~kg}, 5 \mathrm{~kg}$ dan $10 \mathrm{~kg}$, misalkan pengguna memilih isi beras $5 \mathrm{~kg}$, maka state Q1 akan menuju ke state Q7, kemudian muncul total pembayaran dan pilihan metode bayar, jika pengguna memilih metode pembayaran tunai maka state Q7 akan menuju ke state Q9, jika memilih pembayaran non-tunai maka state Q7 akan menuju ke state Q10, setelah itu struk bukti pembelian beras akan keluar bersamaan dengan keluarnya beras. 


\subsection{Perancangan VM Beras}

\subsubsection{Use Case Diagram}

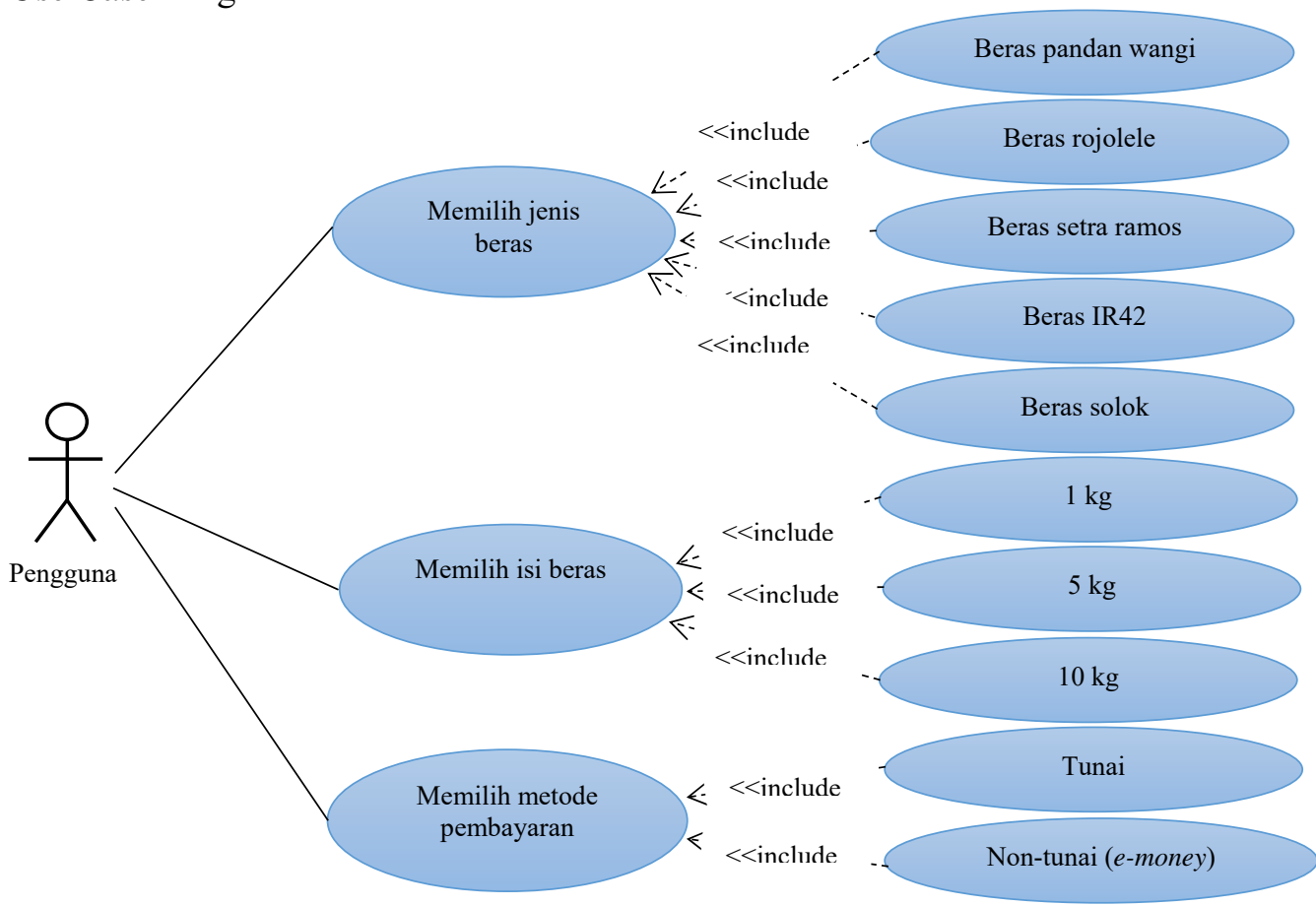

Gambar 3. Use Case Diagram VM Beras

Gambar 3 menjelaskan use case diagram dengan aktor pengguna dapat memilih jenis beras, memilih isi beras dan memilih metode pembayaran secara tunai atau non-tunai.

\subsubsection{Activity Diagran}

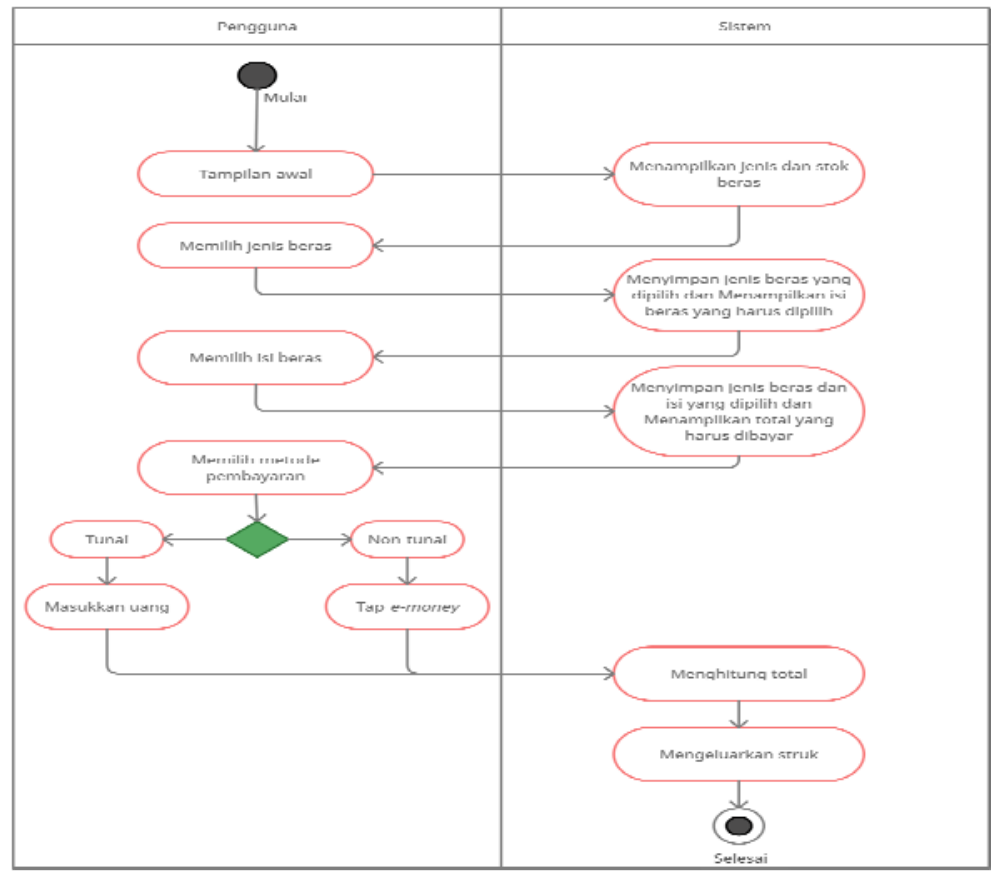

Gambar 4. Activity Diagram VM Beras

JURNAL ILMIAH ELEKTRONIKA DAN KOMPUTER Vol. 14, No. 1, Desember 2021 : 130 -140 
Gambar 4 menampilkan activity diagram VM beras. Hal pertama yang dilakukan pengguna saat VM menunjukan tampilan awal jenis-jenis beras yaitu memilih jenis beras sesuai yang diinginkan, kemudian sistem VM akan menampilkan pilihan isi beras, pengguna dapat memilih isi beras sesuai yang diinginkan, setelah proses pemilihan dilakukan, sistem VM akan memberi tanda jenis beras dan isi beras yang telah dipilih, kemudian harga akan tampil di layar.

Pengguna dapat memilih metode pembayaran tunai maupun metode pembayaran non-tunai. Jika pengguna memilih metode pembayaran tunai maka pengguna memasukkan uang tunai, apabila jumlah yang dimasukkan belum sesuai dengan jumlah yang harus dibayarkan, maka pengguna harus memilih pembayaran tunai lagi dan sistem akan menyimpan uang, jika uang yang dimasukkan lebih maka sistem akan mengeluarkan kembalian dan struk akan keluar atau tercetak.

Pada saat pengguna memilih metode pembayaran non-tunai, maka sistem akan mengaktifkan tempat tapping e-money dan pengguna dapat menempelkan kartu e-money tersebut, kemudian sistem akan membaca pembayaran otomatis dari e-money dan struk akan keluar.

\subsubsection{Desain VM Beras}

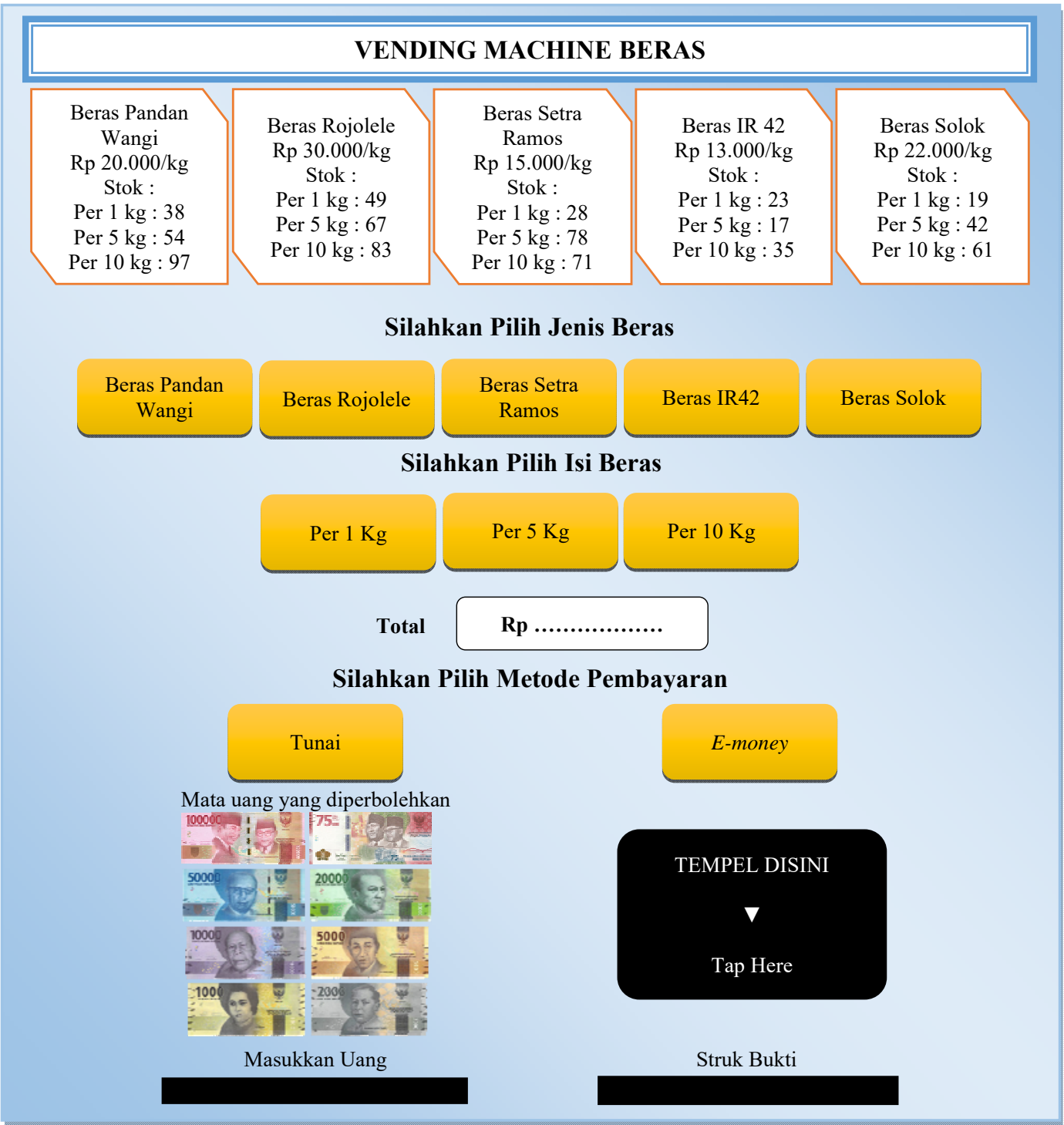

Gambar 5. Tampilan VM Beras

Penerapan Konsep Finite State Automata Pada Aplikasi Simulasi Vending Machine Beras

(Anggun Yuli Asih) 
Gambar 5 merupakan tampilan antar muka desain VM beras. Proses pertama yang dilakukan pada VM beras ini yaitu menampilkan harga per kilo setiap jenis beras beserta stok beras yang tersedia dari VM beras ini. Pengguna dapat langsung memilih jenis beras yang akan dibeli, kemudian memilih isi beras yang diinginkan, setelah itu akan muncul total harga yang harus dibayar dan kemudian akan tampil pilihan metode pembayarannya. Jika pengguna memilih metode pembayaran tunai maka tempat memasukkan uang akan aktif dengan ditandai lampu tempat uang yang menyala dan pengguna dapat langsung memasukkan jenis uang yang diterima mesin, apabila uang yang dimasukkan kurang dari total bayar maka pengguna harus memasukkan uang kembali sampai jumlahnya sesuai, jika pembayaran yang dilakukan melebihi total bayar maka mesin akan otomatis mengembalikan uang kembalian dan struk bukti pembelian beras akan keluar dan pengguna dapat mengambil beras yang sudah dikeluarkan VM berdasarkan jenis beras yang sudah pengguna pilih. Jika pengguna memilih metode pembayaran non-tunai, tempat tapping e-money akan menyala maka pengguna dapat menempelkan kartu e-money pada tempatnya dan mesin akan membaca otomatis total pembayaran kemudian struk akan keluar dan mengeluarkan beras pada tempatnya.

\section{KESIMPULAN}

Berdasarkan perancangan FSA, dapat disimpulkan bahwa penggunaan non-deterministic finite state automata pada desain mesin penjualan beras otomatis dapat bermanfaat bagi pengguna untuk lebih mengefisienkan waktu berbelanja khususnya belanja beras, dan dapat menjadi salah satu faktor pemutus rantai penyebaran virus karena dapat menghindari dari kerumunan seperti di pasar. VM beras ini menggunakan metode pembayaran secara tunai dan non-tunai dengan $e$ money sehingga dapat mempermudah pengguna dalam melakukan pembayaran sesuai yang diinginkan. Saran untuk penelitian selanjutnya adalah perlu adanya pengembangan VM dengan menambahkan fitur pembayaran tunai dengan jenis uang koin, pembayaran non-tunai lainnnya dan fitur isi saldo e-money.

\section{DAFTAR PUSTAKA}

[1] R. Zaeroni and S. Rustariyuni, "Pengaruh Produksi Beras, Konsumsi Beras Dan Cadangan Devisa Terhadap Impor Beras Di Indonesia," E-Jurnal Ekon. Pembang. Univ. Udayana, vol. 5, no. 9, pp. 993-1010, 2016.

[2] N. R. Yunus and A. Rezki, "Kebijakan Pemberlakuan Lock Down Sebagai Antisipasi Penyebaran Corona Virus Covid-19," SALAM J. Sos. dan Budaya Syar-i, vol. 7, no. 3, pp. 227-238, 2020, doi: 10.15408/sjsbs.v7i3.15083.

[3] S. Mashabi, "UPDATE: Tambah 5.862, Kasus Covid-19 Indonesia Kini 1.803.361 Orang," PT. Kompas Cyber Media (Kompas Gramedia Digital Group), 2021. https://nasional.kompas.com/read/2021/05/28/16151881/update-tambah-5862-kasuscovid-19-indonesia-kini-1803361-orang.

[4] M. Masyhuri and S. W. Utomo, "Analisis Dampak Keberadaan Pasar Modern Terhadap Pasar Tradisional Sleko di Kota Madiun," Assets J. Akunt. dan Pendidik., vol. 6, no. 1, p. 59, 2017, doi: 10.25273/jap.v6i1.1293.

[5] S. T. Yuliani, B. Sudarsono, and A. P. Wijaya, "Jurnal Geodesi Undip," Apl. Sist. Inf. Geogr. UNTUK PEMETAAN PASAR Tradis. DI KOTA SEMARANG Berbas. WEB, vol. 5, no. Sistem Informasi Geografis, pp. 208-216, 2016.

[6] D. Sujana, K. M. Sari, and N. M. Ulum, "Analisa Sistem Dan Implementasi Pada Vending Machine Red Boks Di Gedung A UNIS Tangerang Dengan Menggunakan Metode Finite State Automata ( FSA )," Jutis, vol. 6, no. 2, pp. 67-70, 2018.

[7] A. A. Fardhani, D. I. N. Simanjuntak, and A. Wanto, "Prediksi Harga Eceran Beras Di Pasar Tradisional Di 33 Kota Di Indonesia Menggunakan Algoritma Backpropagation," J. Infomedia, vol. 3, no. 1, 2018, doi: 10.30811/jim.v3i1.625.

[8] D. Ricardo and G. Gasim, "Perbandingan Akurasi Pengenalan Jenis Beras dengan

JURNAL ILMIAH ELEKTRONIKA DAN KOMPUTER Vol. 14, No. 1, Desember 2021 : 130 -140 
Algoritma Propagasi Balik pada Beberapa Resolusi Kamera,” J. RESTI (Rekayasa Sist. dan Teknol. Informasi), vol. 3, no. 2, pp. 131-140, 2019, doi: 10.29207/resti.v3i2.894.

[9] B. W. Yohanes, T. Robert, and S. Nugroho, "Sistem Penerjemah Bahasa Jawa-Aksara Jawa Berbasis Finite State Automata," J. Nas. Tek. Elektro dan Teknol. Inf., vol. 6, no. 2, 2017, doi: 10.22146/jnteti.v6i2.306.

[10] R. A. Ma'arif and F. Fauziah, "Implementasi Finite State Automata (FSA) dalam Proses Pengisian Kartu Rencana Studi," JOINTECS (Journal Inf. Technol. Comput. Sci., vol. 3, no. 3, pp. 115-120, 2018, doi: 10.31328/jointecs.v3i3.816.

[11] T. H. Wicaksono, F. D. Amrizal, and H. A. Mumtahana, "Pemodelan Vending Machine dengan Metode FSA ( Finite State Automata )," DoubleClick J. Comput. Inf. Technol., vol. 2, no. 2, pp. 66-69, 2019, [Online]. Available: http://ejournal.unipma.ac.id/index.php/doubleclick.

[12] K. Handayani, D. Ismunandar, S. A. Putri, and W. Gata, "Penerapan Finite State Automata Pada Vending Machine Susu Kambing Etawa," Matics J. Ilmu Komput. dan Teknol. Inf., vol. 12, no. 2, pp. 87-92, 2020, doi: 10.18860/mat.v12i2.9270.

[13] E. Erni, F. Titiani, S. A. Putri, and W. Gata, "Penerapan Konsep Finite State Automata Pada Aplikasi Simulasi Vending Machine Jamu Tradisional," J. Inform., vol. 7, no. 2, pp. 141-147, 2020, doi: 10.31294/ji.v7i2.8151.

[14] R. A. Nugraha, A. Mulyani, and W. Gata, "Desain Vending Machine Rujak Buah Dengan Finite State Automata," IJCIT (Indonesian J. Comput. Inf. Technol., vol. 5, no. September, pp. 198-207, 2020.

[15] A. Faisal, G. V. Saragih, and W. Gata, "Desain Vending Machine Rokok Dengan Mengimplementasikan Finite State Automata Terintegrasi Dengan E-KTP," Matics, vol. 12, no. 1, p. 55, 2020, doi: 10.18860/mat.v12i1.8693.

[16] T. I. Saputra, F. Fauziah, and A. Gunaryati, "Simulasi Vending Machine Dengan Mengimplementasikan Finite State Automata," JOINTECS (Journal Inf. Technol. Comput. Sci., vol. 3, no. 3, pp. 143-148, 2018, doi: 10.31328/jointecs.v3i3.819.

[17] Fergie Joanda Kaunang, "Penerapan Konsep Finite State Automata ( FSA ) pada Mesin The Implementation of Finite State Automata in an Automatic Ice cream Maker Machine," Penerapan Konsep Finite State Autom. pada Mesin Pembuat Ice cream Otomatis, vol. 9, no. 2, pp. 129-137, 2019.

Penerapan Konsep Finite State Automata Pada Aplikasi Simulasi Vending Machine Beras 